\title{
Acute heat stress and dietary methionine effects on IGF-I, GHR, and UCP mRNA expression in liver and muscle of quails
}

\author{
A.P. Del Vesco ${ }^{1}$, E. Gasparino ${ }^{1}$, V. Zancanela ${ }^{1}$, D.O. Grieser ${ }^{1}$, \\ S.E.F. Guimarães ${ }^{2}$, C.S. Nascimento ${ }^{2}$, D.M. Voltolini' ${ }^{1}$, J. Constantin ${ }^{3}$ \\ and F.S. Gasparin ${ }^{3}$ \\ ${ }^{1}$ Departamento de Zootecnia, Universidade Estadual de Maringá, \\ Maringá, PR, Brasil \\ ${ }^{2}$ Departamento de Zootecnia, Universidade Federal de Viçosa, \\ Viçosa, MG, Brasil \\ ${ }^{3}$ Departamento de Bioquímica, Universidade Estadual de Maringá, \\ Maringá, PR, Brasil \\ Corresponding author: A.P. Del Vesco \\ E-mail: egasparino@uem.br
}

Genet. Mol. Res. 13 (3): 7294-7303 (2014)

Received March 28, 2013

Accepted August 20, 2013

Published February 13, 2014

DOI http://dx.doi.org/10.4238/2014.February.13.12

\begin{abstract}
This study evaluated the expression of insulin-like growth factor I (IGF-I), growth hormone receptor (GHR), and uncoupling protein (UCP) mRNA in muscle and liver of quails that were in thermal comfort or exposed to heat stress and that were fed diets with or without methionine supplementation. Meat quails were fed a diet that either met the nutritional demands for methionine (MS) or did not meet this demand (methioninedeficient diet, MD). The animals were either kept at a thermal comfort temperature $\left(25^{\circ} \mathrm{C}\right)$ or exposed to heat stress $\left(38^{\circ} \mathrm{C}\right.$ for $24 \mathrm{~h}$ starting on the 6th day). RNA was extracted from liver and breast muscle, and cDNA was synthesized and amplified using quantitative reverse transcriptionpolymerase chain reaction. Animals that were fed the MS diet and remained at the thermal comfort temperature exhibited increased IGF-I mRNA
\end{abstract}


expression in the liver ( $0.56 \mathrm{AU})$. The GHR mRNA expression in the liver and muscle was influenced by both the study variables. Animals receiving the MS diet showed higher GHR expression, while increased expression was observed in animals at the thermal comfort temperature. The UCP mRNA expression in the muscle was influenced by both methionine supplementation and heat stress. Higher expression was observed in animals that received the MD diet (2.29vs $3.77 \mathrm{AU})$ and in animals kept in thermal comfort. Our results suggest that heat stress negatively affects the expression of growth-related genes and that methionine supplementation is necessary to appropriately maintain the levels of IGF-I, GHR, and UCP transcripts for animal metabolism.

Key words: Growth hormone receptor; Insulin-like growth factor I; Heat stress; Methionine; Uncoupling protein

\section{INTRODUCTION}

The growth rate is related to the feed efficiency and the deposition of muscle mass. The efficiency of an animal to convert food into muscle is related to the efficiency of energy production. Studies show that birds with lower ATP production because of lower efficiency of ATP production from substrate in the mitochondria have poor feed efficiency or feed conversion (Bottje and Carstens, 2009). The efficiency of energy production depends on not only perfect coordination between the respiratory chain complexes but also the availability of nutrients and an antioxidant system that protects the mitochondria from damage that is generated during the production of ATP.

The broiler performance is also affected by the environmental conditions to which the animals are exposed. High environmental temperatures cause low feed intake, poor nutrient utilization efficiency, low weight gain, low egg production, and poor feed efficiency (Akşit et al., 2006; Menten et al., 2006). This negative effect on performance is mainly a result of reduced T3 and T4 levels, changes in water and ion balances, the kinetics of important enzymes that change the ratio of anabolic and catabolic products, immune depression, and changes in growth hormone levels (Barbour et al., 2010).

In addition to environmental temperature (Gabillard et al., 2003, 2006), studies show that the expression of growth-related hormones, such as insulin-like growth factor I (IGF-I) and growth hormone receptor (GHR), may be influenced by other factors, such as nutrition (Katsumata et al., 2002; Gasparino et al., 2012). According to Kimball and Jefferson (2004), amino acids play a key role in regulating some cellular processes, such as the regulation of gene expression by mRNA modulation. Still, according to these authors, the cells are able to recognize the availability of amino acids and generate changes in translational signaling pathways, which are also regulated by hormones and growth factors.

Because of its importance in the deposition of muscle tissue and feathers, and in biochemical processes (donor of methyl groups, -CH3), methionine is the first limiting amino acid for broilers. The requirement of methionine and cystine (Met + Cys) depends on the performance parameters that are evaluated, with a higher requirement of sulfur amino acids for feed conversion and breast yield than for weight gain (Schutte and Pack, 1995). The main 
function of methionine is to allow the animal growth (muscle mass). However, methionine has a complex metabolism that is involved in several functions in the animal organism, such as the methylation of RNA, DNA, proteins, and lipids, and the production of various cellular components, such as glutathione, which is the main antioxidant system in the cytosol of the cells, polyamines (spermine and spermidine), taurine, which facilitates the digestion of lipids and also acts as an antioxidant in the cell membrane (Stipanuk, 2004), and $\mathrm{H}_{2} \mathrm{~S}$, which has an anti-inflammatory action (Bauchart-Thevret et al., 2009).

This study was performed to test the hypothesis that heat stress (HS) can damage cellular metabolism, influencing the expression of genes related to growth and ATP production, and that supplementing methionine could minimize the HS effect on the expression of such genes. Thus, this study aimed to evaluate the expression of IGF-I, GHR, and uncoupling protein (UCP) mRNA in muscle and liver of quails that were in thermal comfort or exposed to HS $\left(38^{\circ} \mathrm{C}\right.$ for $\left.24 \mathrm{~h}\right)$ and that were fed diets with or without methionine supplementation.

\section{MATERIAL AND METHODS}

The experimental procedure was approved by the Brazilian Animal Ethics Committee. The experiment was conducted on the Iguatemi Experimental Farm of the Universidade Estadual de Maringá - UEM. Sixty-four meat quails (Coturnix coturnix coturnix) were raised conventionally until 35 days of age and were fed a balanced diet to meet their nutritional demands. After 35 days, the animals were divided into 4 groups $(\mathrm{N}=16$ per group) and transferred to temperature-controlled rooms (room 1 and 2; 2 groups per room), where they remained for 7 days while adapting to the thermal comfort temperature: $25^{\circ} \pm 0.9^{\circ} \mathrm{C}$ with $60 \pm 1.2 \%$ relative humidity. The temperature chosen for thermal comfort followed the recommendations of Pinto et al. (2003). In each room, 1 group received feed that was calculated to meet the nutritional demand for methionine (MS) according to Rostagno et al. (2011), and the other group received feed without methionine supplementation (methionine-deficient diet, MD) (Table 1). Animals in room 1 were kept at thermal comfort during the 7 days of evaluation, while animals in room 2 were kept at thermal comfort for 6 days. At the end of the 6th day, these animals were subjected to $\mathrm{HS}$ of $38^{\circ} \mathrm{C}$ for $24 \mathrm{~h}$. All animals were sacrificed by cervical dislocation at the end of the 7 th day. Water and feed intake were measured during the full-thermal comfort period and the $24 \mathrm{~h}$ of stress, and it was calculated as the difference between the amount of feed offered and the feed residue at the end of the trial. The feed conversion ratio was calculated by dividing feed intake by weight gain, and it was corrected for mortality. To calculate the weight gain of the quails under thermal comfort and stress conditions, the specimens were weighed individually at the beginning and the end of the thermal comfort and stress periods, respectively.

For gene expression analysis, samples of the liver and breast muscle (pectoralis superficialis) were collected and stored in RNA Holders (BioAgency Biotecnologia, São Paulo, SP, Brazil) at $-20^{\circ} \mathrm{C}$ until total RNA extraction.

Total RNA was extracted using the Trizol reagent (Invitrogen, Carlsbad, CA, USA), according to manufacturer instructions, at a ratio of $1 \mathrm{~mL}$ for every $100 \mathrm{mg}$ tissue. All utilized materials were previously treated with an RNase inhibitor (RNase AWAYs, Invitrogen). Tissue specimens with Trizol were ground using an electric Polytron homogenizer until their complete dissociation, after which, $200 \mu \mathrm{L}$ chloroform was added, and the samples were manually homogenized for $1 \mathrm{~min}$. Samples were then centrifuged for $15 \mathrm{~min}$ at $12,000 \mathrm{rpm}$ and $4^{\circ} \mathrm{C}$, the liquid 
phase was collected and transferred to clean tube, and $500 \mu \mathrm{L}$ isopropanol was added. Samples were again homogenized and centrifuged for $15 \mathrm{~min}$ at $12,000 \mathrm{rpm}$ and $4^{\circ} \mathrm{C}$. The supernatant was discarded, and the precipitate was washed in $1 \mathrm{~mL} \mathrm{75 \%} \mathrm{ethanol.} \mathrm{The} \mathrm{material} \mathrm{was} \mathrm{again} \mathrm{centri-}$ fuged for $5 \mathrm{~min}$ at 12,000 rpm, and the supernatant was discarded. The pellet was dried for $15 \mathrm{~min}$ and then resuspended in RNAase-free ultrapure water.

\section{Table 1. Experimental diets (centesimal composition expressed as fed basis).}

\begin{tabular}{lrr}
\hline Ingredients & & Experimental diets \\
\cline { 2 - 3 } & MS & MD \\
\hline Corn 7.8\% crude protein (CP) & 58.25 & 58.40 \\
Soy bean meal 46.7\% CP & 35.40 & 35.40 \\
Soy oil & 2.40 & 2.50 \\
Salt & 0.40 & 0.40 \\
Calcareous 38\% & 1.34 & 1.34 \\
Dicalcium phosphate 20\% & 1.33 & 1.33 \\
DL-methionine 99\% & 0.27 & - \\
L-lysine HCl 78\% & 0.15 & 0.15 \\
L-treonine 78\% & 0.06 & 0.06 \\
Premix* & 0.40 & 0.4 \\
Total & 100.00 & 100.00 \\
Composition analysis (\%) & & \\
CP & 21.16 & 21.02 \\
Lysine digestible & 1.15 & 1.15 \\
Met+Cys digestible & 0.84 & 0.57 \\
Treonine digestible & 0.78 & 0.78 \\
Triptophane digestible & 0.23 & 0.23 \\
Valine digestible & 0.90 & 0.90 \\
Isoleucine digestible & 0.83 & 0.83 \\
Arginine digestible & 1.33 & 1.33 \\
Composition calculated $(\%) \dagger$ & & \\
Ca & & 0.90 \\
P & 0.90 & 0.41 \\
Na & 0.41 & 0.18 \\
AME (kcal/kg) & 0.18 & 3000.08 \\
\hline MS
\end{tabular}

$\mathrm{MS}=$ methionine supplementation; $\mathrm{MD}=$ methionine deficient. *Supplied by kilogram of diet: retinyl-acetate, 3.44 $\mathrm{mg}$; cholecalciferol, $50 \mu \mathrm{g}$; DL- $\alpha$-tocopherol, $15 \mathrm{mg}$; thiamine, $1.63 \mathrm{mg}$; riboflavin, $4.9 \mathrm{mg}$; pyridoxine, $3.26 \mathrm{mg}$; cyanocobalamin, $12 \mu \mathrm{g}$; D-pantothenic acid, $9.8 \mathrm{mg}$; D-biotin, $0.1 \mathrm{mg}$; menadione, $2.4 \mathrm{mg}$; folic acid, $0.82 \mathrm{mg}$; niacinamide, $35 \mathrm{mg}$; selenium, $0.2 \mathrm{mg}$; iron, $35 \mathrm{mg}$; copper, $8 \mathrm{mg}$; manganese, $60 \mathrm{mg}$; zinc, $50 \mathrm{mg}$; iodine, $1 \mathrm{mg}$; choline, $650 \mathrm{mg}$; salinomycin, $60 \mathrm{mg}$; avilamycin, $5 \mathrm{mg}$; butyl hydroxy toluene, $80 \mathrm{mg}$.

The total RNA concentration was measured using a spectrophotometer at a wavelength of $260 \mathrm{~nm}$. The integrity of the RNA was evaluated on a $1 \%$ agarose gel in the presence of $0.5 \mathrm{mg} / \mathrm{mL}$ ethidium bromide and visualized with ultraviolet light. RNA samples were treated with DNase I (Invitrogen) to remove possible genomic DNA contamination according to manufacturer recommendations.

Complementary DNA (cDNA) was prepared using the SuperScript ${ }^{\mathrm{TM}}$ First-Strand Synthesis Super Mix kit (Invitrogen Corporation, Brazil), according to manufacturer instructions. The cDNA mixture contained $6 \mathrm{~mL}$ total RNA, $1 \mathrm{~mL}$ oligo (dT: $50 \mu \mathrm{M}$ oligo (dT)20) and $1 \mathrm{~mL}$ annealing standard. The reaction was incubated for $5 \mathrm{~min}$ at $65^{\circ} \mathrm{C}$ and then placed on ice for 1 min. Subsequently, $10 \mu \mathrm{L} 2 \mathrm{X}$ First-Strand Reaction Mix and $2 \mu \mathrm{L}$ solution containing the enzyme reverse transcriptase SuperScript III and RNAase inhibitor were added. The solution was incubated for $50 \mathrm{~min}$ at $50^{\circ} \mathrm{C}$ to allow cDNA to be synthesized. The reaction was then incubated for $5 \mathrm{~min}$ at $85^{\circ} \mathrm{C}$ and immediately placed on ice. Samples were stored at $-20^{\circ} \mathrm{C}$ until analysis. 
Real-time PCR used the fluorescent dye SYBR GREEN (SYBR GREEN PCR Master Mix, Applied Biosystems, Carlsbad, CA, USA). Real-time PCR analyses were performed in the apparatus StepOnePlus v.2.2 (Applied Biosystems). All reactions were performed under the same analysis conditions and were normalized by the signal of a passive reference dye (ROX Reference Dye, Invitrogen) to correct reading fluctuations caused by volume variations and evaporation during the reaction.

The UCP primers that were used in the reactions were designed according to OjanoDirain et al. (2007), and the GHR and IGF-I primers were designed at [www.idtdna.com], using gene sequences from [www.ncbi.nlm.nih.gov] (accession Nos. NM001001293.1 and FJ977570.1, respectively) (Table 2). We tested 2 housekeeping genes, the $\beta$-actin and glyceraldehyde 3-phosphate dehydrogenase (GAPDH) genes, and we used the GAPDH gene (accession No. NM_204305) because it presented better efficiency in the reaction. All analyses were performed in a volume of $25 \mu \mathrm{L}$ and in duplicate.

Table 2. Primer sequences used for quantitative real-time polymerase chain reaction.

\begin{tabular}{lccl}
\hline Gene & Amplicom $(\mathrm{bp})$ & Annealing temperature $\left({ }^{\circ} \mathrm{C}\right)$ & Primer sequences $\left(5^{\prime}-3^{\prime}\right)$ \\
\hline GHR & 145 & 60 & $\begin{array}{l}\text { AACACAGATACCCAACAGCC } \\
\text { AGAAGTCAGTGTTTGTCAGGG } \\
\text { CACCTAAATCTGCACGCT }\end{array}$ \\
IGF-I & 140 & 60 & CTTGTGGATGGCATGATCT \\
GCAGCGGCAGATGAGCTT & AGAGCTGCTTCACAGAGTCGTAGA \\
UCP & 41 & 60 & GTTCTGTTCCCTTCTGTCTC \\
GTTTCTATCAGCCTCTCCCA
\end{tabular}

The $2^{-\Delta \mathrm{Ct}}$ method was used to analyze the relative expression. The results are reported as averages and standard deviations. The UNIVARIATE procedure was applied to evaluate data normality. The experiment was conducted in a completely randomized factorial design, with 2 environments (thermal comfort and HS) and 2 methionine supplementation hypotheses (MS and MD). The averages were compared using the Tukey test $(\mathrm{P}<0.05)$ (SAS Inst. Inc., Cary, NC, USA).

\section{RESULTS}

Methionine supplementation did not affect water and feed intakes and daily weight gain (DWG); however, HS significantly increased water intake and decreased feed intake and DWG (1.63 vs 0.04) (Figure 1).

The effect of the interaction between diet and temperature on the expression of IGF-I mRNA in the liver was observed. Animals fed the MS diet that remained at the thermal comfort temperature exhibited increased IGF-I expression (0.56 AU), and lower IGF-I mRNA expression was observed in animals that were fed the MD diet in comfort and HS (0.19 and $0.24 \mathrm{AU}$, respectively).

The expression of GHR mRNA in the liver was influenced by both the study variables. Animals receiving the MS diet showed higher expression (309.93 AU) than those receiving the MD diet, and increased expression was observed in animals from the thermal comfort condition (309.72 AU). 
a
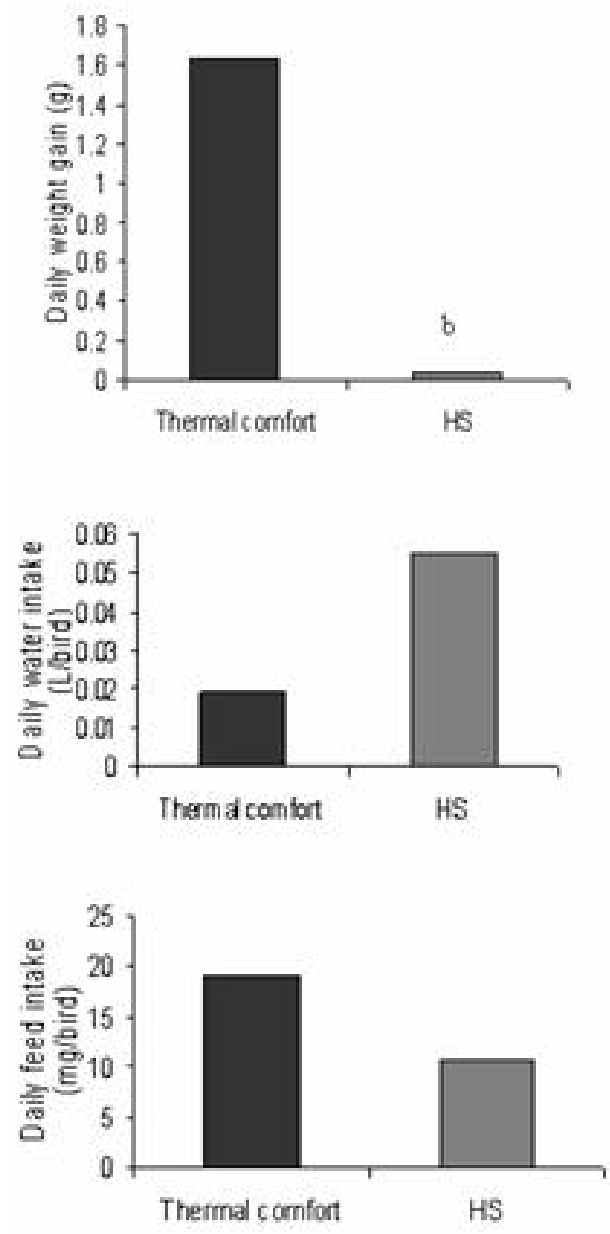
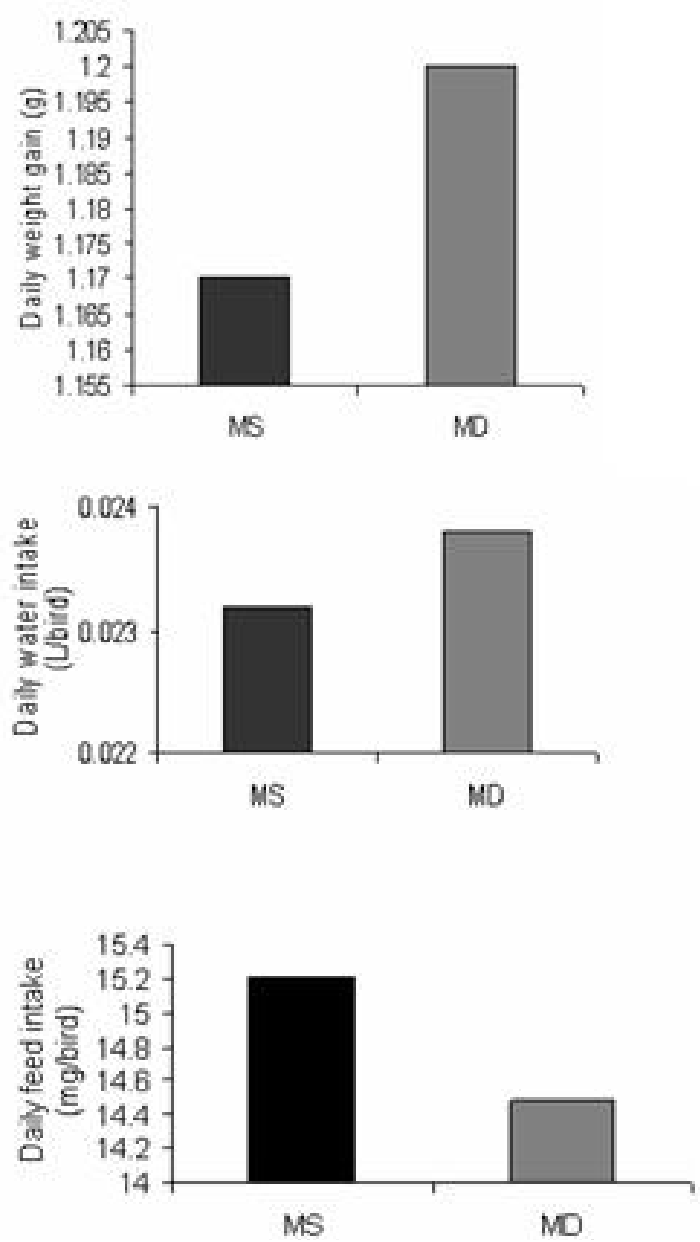

Figure 1. Daily weight gain and daily water and feed intake of quails in thermal comfort or heat stress (HS) and fed with methionine supplementation (MS) diet or methionine-deficient (MD) diet.

The expression of UCP mRNA was influenced only by diet. Animals fed the MD diet showed increased expression of UCP mRNA in the liver (0.040 AU) (Table 3).

In the muscle, no effect of the interaction between diet and temperature on the expression of the evaluated genes was observed. IGF-I expression was influenced only by diet. Animals fed the MS diet showed increased expression of IGF-I mRNA in the muscle (0.025 AU) (Table 4).

The highest GHR mRNA expression was observed in animals fed the MS diet ( 0.48 AU). Regarding environment, HS caused lower GHR mRNA expression than the thermal comfort condition.

UCP mRNA expression was influenced by both methionine supplementation and HS. Higher expression was observed in animals that received the MD diet (3.77 AU) and in animals kept in thermal comfort (3.41 AU) (Table 4). 
Table 3. Expression of IGF-I, GHR and UCP genes in the liver of quails.

\begin{tabular}{|c|c|c|c|c|c|c|}
\hline & \multicolumn{2}{|c|}{ IGF-I } & \multicolumn{2}{|c|}{ GHR } & \multicolumn{2}{|c|}{ UCP } \\
\hline & Mean & $\mathrm{SD}$ & Mean & SD & Mean & SD \\
\hline \multicolumn{7}{|l|}{ MS } \\
\hline Comfort & $0.56^{\mathrm{a}}$ & 0.06 & 314.71 & 44.66 & 0.028 & 0.002 \\
\hline Stress & $0.47^{\mathrm{b}}$ & 0.03 & 305.14 & 34.43 & 0.029 & 0.004 \\
\hline \multicolumn{7}{|l|}{$\mathrm{MD}$} \\
\hline Comfort & $0.19^{\mathrm{c}}$ & 0.02 & 304.73 & 41.99 & 0.036 & 0.004 \\
\hline Stress & $0.24^{\mathrm{c}}$ & 0.03 & 217.89 & 32.01 & 0.045 & 0.008 \\
\hline \multicolumn{7}{|l|}{ Main effects } \\
\hline MS & 0.51 & 0.06 & $309.93^{\mathrm{a}}$ & 37.27 & $0.028^{\mathrm{b}}$ & 0.003 \\
\hline MD & 0.21 & 0.04 & $261.31^{\mathrm{b}}$ & 57.88 & $0.040^{\mathrm{a}}$ & 0.008 \\
\hline \multicolumn{7}{|l|}{ Environment } \\
\hline Comfort & 0.37 & 0.002 & $309.72^{\mathrm{a}}$ & 40.47 & 0.037 & 0.010 \\
\hline Stress & 0.35 & 0.001 & $261.52^{b}$ & 55.88 & 0.032 & 0.005 \\
\hline \multicolumn{7}{|l|}{ Probabilities } \\
\hline Diet & $<0.0001$ & & 0.0271 & & 0.0004 & \\
\hline Environment & 0.3841 & & 0.0281 & & 0.0737 & \\
\hline Interaction & 0.0036 & & 0.0686 & & 0.1430 & \\
\hline
\end{tabular}

$\mathrm{MS}=$ methionine supplementation; $\mathrm{MD}=$ methionine deficient. ${ }^{\mathrm{a}, \mathrm{b}, \mathrm{c}}$ Mean values within a row with unlike superscript letters are significantly different $(\mathrm{P}<0.05)$.

Table 4. Expression of IGF-I, GHR and UCP genes in the muscle of quails.

\begin{tabular}{|c|c|c|c|c|c|c|}
\hline & \multicolumn{2}{|c|}{ IGF-I } & \multicolumn{2}{|c|}{ GHR } & \multicolumn{2}{|c|}{$\mathrm{UCP}$} \\
\hline & Mean & SD & Mean & $\mathrm{SD}$ & Mean & $\mathrm{SD}$ \\
\hline \multicolumn{7}{|l|}{$\overline{\mathrm{MS}}$} \\
\hline Comfort & 0.026 & 0.0035 & 0.57 & 0.09 & 2.76 & 0.19 \\
\hline Stress & 0.025 & 0.0016 & 0.39 & 0.04 & 1.81 & 0.12 \\
\hline \multicolumn{7}{|l|}{ MD } \\
\hline Comfort & 0.014 & 0.0016 & 0.44 & 0.05 & 4.06 & 0.48 \\
\hline Stress & 0.013 & 0.0010 & 0.23 & 0.01 & 3.48 & 0.14 \\
\hline \multicolumn{7}{|l|}{ Main effects } \\
\hline MS & $0.025^{\mathrm{a}}$ & 0.003 & $0.48^{\mathrm{a}}$ & 0.12 & $2.29^{\mathrm{b}}$ & 0.53 \\
\hline MD & $0.014^{b}$ & 0.001 & $0.34^{\mathrm{b}}$ & 0.12 & $3.77^{\mathrm{a}}$ & 0.45 \\
\hline \multicolumn{7}{|l|}{ Environment } \\
\hline Comfort & 0.020 & 0.007 & $0.51^{\mathrm{a}}$ & 0.098 & $3.41^{\mathrm{a}}$ & 0.77 \\
\hline Stress & 0.019 & 0.006 & $0.31^{\mathrm{b}}$ & 0.087 & $2.65^{\mathrm{b}}$ & 0.89 \\
\hline \multicolumn{7}{|l|}{ Probabilities } \\
\hline Diet & $<0.0001$ & & 0.0003 & & $<0.0001$ & \\
\hline Environment & 0.3268 & & $<0.0001$ & & 0.0001 & \\
\hline Interaction & 0.8497 & & 0.6777 & & 0.2106 & \\
\hline
\end{tabular}

$\mathrm{MS}=$ methionine supplementation; $\mathrm{MD}=$ methionine deficient. ${ }^{\mathrm{a}, \mathrm{b}}$ Mean values within a row with unlike superscript letters are significantly different $(\mathrm{P}<0.05)$.

\section{DISCUSSION}

In animal production, performance (e.g., feed and reproduction efficiency) is expressed according to the animal's genetic background, the environment to which it is exposed, and the interaction between genetics and the environment. Thus, this study was conducted to test the hypothesis that methionine supplementation could mitigate the deleterious effects of HS on cell metabolism.

Animal growth is mainly due to protein deposition, which is given by a balance between protein synthesis and degradation. Reports suggest that these 2 distinct paths are prod- 
ucts of the same biological pathways (Sacheck et al., 2004), and that hormone concentrations and diet are factors that can determine which of these paths will prevail.

Supplementing methionine in the diet may lead to protein deposition by stimulating body protein synthesis through the induction of greater amounts of IGF-I and GHR. Although how changes in amino acid supplementation can initiate changes in expression of genes such as GH and IGF-I is not yet fully clarified, it is suggested that the mammalian target of rapamycin (mTOR) activity, an enzyme involved in regulating protein synthesis, may mediate this effect (Stubbs et al. 2002).

We observed that IGF-I and GHR mRNA expression was lower in both tissues that were evaluated in animals receiving the MD diet and in those exposed to HS. In the literature, it is possible to find other results about the influence of diet on somatotropic axis gene expression (Louveau and Le Dividich, 2002; Stubbs et al., 2002). According to Stubbs et al. (2002), the lower IGF-I mRNA expression in the liver of sheep may be because of the ability of methionine to affect the release of IGF-I induced by GH. Because the authors did not observe reduced release of IGF-I when the animals received a diet with a reduced total amino acid content, they suggested that restricted methionine can selectively block the transcriptional response to GH and affect the expression of IGF-I in the liver. Louveau and Le Dividich (2002) suggested that reduced IGF-I expression in animals suffering food restriction or a nutrient deprivation may be associated with reduced binding capacity of GH and/or lower levels of GHR in the liver. Therefore, adequate nutrition is indeed required for the maturation of the GH/IGF-I axis.

A result that should be highlighted is that we observed a significant interaction effect on IGF-I mRNA expression in the liver, with the highest expression observed in animals that were maintained in thermal comfort and fed the MS diet. These beneficial effects of methionine supplementation are due in part to the fact that methionine participates in not only protein synthesis but also other important metabolic reactions to maintain adequate performance, such as acting as a donor of methyl groups (Simon, 1999), participating in glutathione synthesis as a sulfur donor (Wu and Davis, 2005), and participating in the synthesis of cysteine and S-adenosylmethionine, which is responsible for the biosynthesis of a variety of cellular compounds, such as creatine, carnitine, phospholipids, and proteins (Stipanuk, 2004).

Regarding HS, we can say that this factor not only influenced the expression of growth-related genes but also reduced the DWG and feed intake. Willemsen et al. (2011) observed lower IGF-I blood levels in broilers that were submitted to HS, which also presented lower T3 and T4 levels, higher corticosterone levels, higher thiobarbituric acid reactive substance concentrations, and higher antioxidant enzyme activity. The authors suggested that HS may trigger oxidative stress, thereby contributing to a lower metabolic rate. Besides reduced production efficiency and induced reactive oxygen species (ROS) production, exposure to high temperatures is also associated with reduced activity of the mitochondrial respiratory chain (Yang et al., 2010).

The production of ROS in animals that are exposed to high temperatures has been correlated with the potential of the mitochondrial membrane and the expression of the UCP gene (Fink et al., 2005). UCPs are transporters in the inner mitochondrial membrane that divert ATP synthesis energy to heat production, which is catalyzed by protons leaking through the inner membrane (Ledesma et al., 2002). A greater membrane potential is related to greater ROS production, and greater UCP mRNA production is associated with the production of fewer free 
radicals and to less cellular damaged as a result of ROS. A greater membrane potential and less avUCP mRNA expression is observed in animals that are subjected to HS (Mujahid et al., 2009; Del Vesco and Gasparino, 2013).

Like in previous studies, we also observed that animals that were maintained in thermal comfort showed higher UCP mRNA expression in muscle and liver than animals that were subjected to HS. Additionally, animals fed the MS diet showed lower expression of UCP mRNA. In this study, methionine supplementation in the diet was studied to evaluate the possible role of this amino acid in UCP mRNA expression, which might thus confer protection against cell damage from oxidative stress.

Our results allow us to suggest that heat stress of $38^{\circ} \mathrm{C}$ for $24 \mathrm{~h}$ negatively affected the expression of genes related to growth, and that methionine supplementation is necessary to appropriately maintain the levels of IGF-I, GHR, and UCP transcripts for animal metabolism.

\section{ACKNOWLEDGMENTS}

The authors are grateful to Procad-CAPES and CNPq.

\section{REFERENCES}

Akşit M, Yalcin S, Ozkan S, Metin K, et al. (2006). Effects of temperature during rearing and crating on stress parameters and meat quality of broilers. Poult. Sci. 85: 1867-1874.

Barbour EK, Tayeb I, Shaib H and Ibraim M (2010). Physiological and carcass traits in heat-stressed broilers differing in heat acclimatization, chemical or feed restriction treatments. Agric. Biol. J. North Am. 1: 65-74.

Bauchart-Thevret C, Stoll B, Chacko S and Burrin DG (2009). Sulfur amino acid deficiency upregulates intestinal methionine cycle activity and suppresses epithelial growth in neonatal pigs. Am. J. Physiol. Endocrinol. Metab. 296: E1239-E1250.

Bottje WG and Carstens GE (2009). Association of mitochondrial function and feed efficiency in poultry and livestock species. J. Anim. Sci. 87: E48-E63.

Del Vesco AP and Gasparino E (2013). Production of reactive oxygen species, gene expression, and enzymatic activity in quail subjected to acute heat stress. J. Anim. Sci. 91: 582-587.

Fink BD, Reszka KJ, Herlein JA, Mathahs MM, et al. (2005). Respiratory uncoupling by UCP1 and UCP2 and superoxide generation in endothelial cell mitochondria. Am. J. Physiol. Endocrinol. Metab. 288: E71-E79.

Gabillard JC, Weil C, Rescan PY, Navarro I, et al. (2003). Effects of environmental temperature on IGF1, IGF2, and IGF type I receptor expression in rainbow trout (Oncorhynchus mykiss). Gen. Comp. Endocrinol. 133: 233-242.

Gabillard JC, Yao K, Vandeputte M, Gutierrez J, et al. (2006). Differential expression of two GH receptor mRNAs following temperature change in rainbow trout (Oncorhynchus mykiss). J. Endocrinol. 190: 29-37.

Gasparino E, Guimaraes SE, Neto AR, Martins EN, et al. (2012). The effect of glycerol on mRNA expression of growth hormone, insulin-like growth factor, and mitochondrial breast muscle genes of Japanese quail. Br. Poult. Sci. 53: 497-507.

Katsumata M, Kawakami S, Kaji Y, Takada R, et al. (2002). Differential regulation of porcine hepatic IGF-I mRNA expression and plasma IGF-I concentration by a low lysine diet. J. Nutr. 132: 688-692.

Kimball SR and Jefferson LS (2004). Molecular mechanisms through which amino acids mediate signaling through the mammalian target of rapamycin. Curr. Opin. Clin. Nutr. Metab. Care 7: 39-44.

Ledesma A, Lacoba MG and Rial E (2002). The mitochondrial uncoupling proteins. Genome Biol. 3: 3015.1-3015.9.

Louveau I and Le Dividich J (2002). GH and IGF-I binding in adipose tissue, liver, and skeletal muscle in response to milk intake level in piglets. Gen. Comp. Endocrinol. 126: 310-317.

Menten JFM, Barbosa Filho JAD, Silva MAN, Silva IJO, et al. (2006). Physiological responses of broiler chickens to preslaughter heat stress. World's Poult. Sci. J. 62: 254-257.

Mujahid A, Akiba Y and Toyomizu M (2009). Olive oil-supplemented diet alleviates acute heat stress-induced mitochondrial ROS production in chicken skeletal muscle. Am. J. Physiol. Regul. Integr. Comp. Physiol. 297: R690-R698.

Ojano-Dirain C, Toyomizu M, Wing T, Cooper M, et al. (2007). Gene expression in breast muscle and duodenum from 
low and high feed efficient broilers. Poult. Sci. 86: 372-381.

Pinto R, Ferreira AS, Donzele JL, Albino LFT, et al. (2003). Exigência de metionina mais cistina para codornas japonesas em crescimento. Rev. Bras. Zootec. 32: 1174-1181.

Rostagno HS, Albino LFT, Donzele JL, Gomes PC, et al. (2011). Brazilian Tables for Birds and Pigs: Composition of Foods and Nutritional Requirements. Universidade Federal de Viçosa, Viçosa.

Sacheck JM, Ohtsuka A, McLary SC and Goldberg AL (2004). IGF-I stimulates muscle growth by suppressing protein breakdown and expression of atrophy-related ubiquitin ligases, atrogin-1 and MuRF1. Am. J. Physiol. Endocrinol. Metab. 287: E591-E601.

Schutte JB and Pack M (1995). Sulfur amino acid requirement of broiler chicks from fourteen to thirty-eight days of age. 1. Performance and carcass yield. Poult. Sci. 74: 480-487.

Simon J (1999). Choline, betaine and methionine interactions in chickens, pigs and fish (including crustaceans). World's Poult. Sci. J. 55: 353-374.

Stipanuk MH (2004). Sulfur amino acid metabolism: pathways for production and removal of homocysteine and cysteine. Annu. Rev. Nutr. 24: 539-577.

Stubbs AK, Wheelhouse NM, Lomax MA and Hazlerigg DG (2002). Nutrient-hormone interaction in the ovine liver: methionine supply selectively modulates growth hormone-induced IGF-I gene expression. J. Endocrinol. 174: 335-341.

Willemsen H, Swennen Q, Everaert N, Geraert PA, et al. (2011). Effects of dietary supplementation of methionine and its hydroxy analog DL-2-hydroxy-4-methylthiobutanoic acid on growth performance, plasma hormone levels, and the redox status of broiler chickens exposed to high temperatures. Poult. Sci. 90: 2311-2320.

Wu G and Davis DA (2005). Interrelationship among methionine, choline, and betaine in channel catfish Ictalurus punctutus. J. World Aquacult. Soc. 36: 337-345.

Yang L, Tan GY, Fu YQ, Feng JH, et al. (2010). Effects of acute heat stress and subsequent stress removal on function of hepatic mitochondrial respiration, ROS production and lipid peroxidation in broiler chickens. Comp. Biochem. Physiol. C Toxicol. Pharmacol. 151: 204-208. 